\title{
MOLECULAR IDENTIFICATION AND BIOMASS PRODUCTION OF AN ENDOPHYTIC Beauveria bassiana ISOLATED FROM CUCUMBER LEAVES IN IRAQ
}

\author{
Feyroz RAmadan Hassan ${ }^{*}$, SAMir Khalaf AbDUllah ${ }^{* *}$ and LAZgeEn HaJi ASSAF ${ }^{* * *}$ \\ *Dept. of Plant Protection, College of Agricultural and Engineering sciences, University of Duhok, \\ Kurdistan Region -Iraq. \\ *** Medical Laboratory Technology Department, Alnoor University College, Nineva-Iraq \\ ${ }^{* * *}$ General Directorate of Agriculture-Duhok, Kurdistan Region- Iraq
}

(Accepted for Publication: October 21, 2019)

\begin{abstract}
Beauveriabassianaas an endophyte fungus was isolated for the first time from cucumber leaves in Duhok province, Kurdistan region, Iraq. The identification was based on molecular and morphological analyses. Morphological description matched well with its molecular analysis using ITS (Internal Transcribed Spacer region). Cultivation of $B$. bassiana isolate on rice and wheat grains as liquid and solid media have shown that the weight, sporulation and germination of the fungus differs significantly between two grains, the maximum weight of the fungus achieved when cultured on rice based medium as liquid (cooked rice) compared to wheat based medium. Inverse results recorded in the case of solid media that the maximum weight of $B$. bassiana achieved on wheat compared to rice medium.
\end{abstract}

KEY WORD: Beauveriabassiana, endophytic fungi, biomass production, cucumber leaves. https://doi.org/10.26682/cajuod.2020.22.2.5

\section{INTRODUCTION}

$\mathbf{T}$ The German scientist Heinrich Anton De Bary (1884)used the term an endophyteto define fungi or bacteria that inhabit the internal tissue of the host plant for all or part of their life cycle (Wilson1995; Hyde andSoytong 2008). They colonize the internal plant tissues beneath the epidermal cell layers without causing any apparent symptoms in the host, living within the intercellular spaces and penetrate the living cells (Strobel2003). According to Huanget al. (2001); Arnold(2007), It has been estimated that there may be as many as one million different endophytic fungal taxa bases on ratio of vascular plants of 1:4-5, and mostly belonging toascomycetes. Few species have been reported from other groups of fungi(ZhengandJiang1995; Norileret al.2018).

NaturallyBeauveriabassianais grows in soils throughout the world, causing white muscardine disease to wide range of arthropods, but this fungus also has been recorded as an endophyte in many plants as: elm bark (DoberskiandTribe 1980), maize (Vakili 1990; Arnold and Lewis
2005), in the bark of Carpinuscarolinana (Bills and Polishook 1991), potato and cotton (Jones 1994), tomato (Leckie 2002), Theobromagileri (Evanset al. 2003), in the seeds and needles of Pinusmonticola (GanleyandNewcombe 2005), and in Opium poppies (Quesada- Moragaet al. 2006), banana (Akelloet al. 2007), coffee (Posadaet al.2007), sorghum (TeferaandVidal2009), wheat, cotton, tomato, bean, pumpkin (Gurulingappaet al. 2010), radiate pine (Brownbridgeet al.2012),common bean (Ramoset al.2017) and Sugarcane (Donga et al.2018).There is a growing interest in applying endophyticentomopathogens in management of insect pests (Vega 2018).There are two principal mass production technologies; combined method (Sikura and Primak 1970) or diphasic production system (Kassaet al. 2008) by using solid material as sorghum, rice, wheat and millet(Leiteet al. 2002; Machadoet al. 2010). The cultivation of microorganisms using any cultured technique needsknowledge of nutritional requirements, which are responsible for the mycelia growth and spore yield. The macro elements as carbon, hydrogen, oxygen, 
sulfur, phosphorous and nitrogen are required which are the basic components of carbohydrates, nucleic acids and proteins.

The present study was carried out to identify the endophytic $B$. bassiana isolated from cucumber leaves depending on both morphological characteristics and molecular identification and evaluate the two grains; rice and wheat as liquid and solid media for it biomass production.

\section{MATERIAL AND METHODS}

\section{Isolation of endophytic fungi}

To isolate endophyticentomopathogenic fungi harboring plants, cucumber plants from different villages related to Amadia district $(1122 \mathrm{~m}$ above sea level) were collected. The plant samples kept in plastic bags and transferred to the laboratory for isolation of the entomopathogenic fungi. For each plant, tissues including leaves, stems and roots were washed by tap water and then surface- sterilized according to Arnold et al.(2007). The tissues well dried on sterile paper towels and the edges were cut to remove dead tissues ensuing from the disinfection process. Five sections of each plant part (root, stem and leaves) were placed in petri dishes of selective media. Four replicates were used/ plant part. The plates incubated at $25^{\circ} \mathrm{C}$ for two weeks. Fungi growing from tissues were transferred on standard PDA medium ((Himedia laboratories Pvt. Ltd.India). for identification.

Isolates recovered from single conidia were grown as mycelia in 250-ml conical flasks containing $100 \mathrm{ml}$ of potato dextrose broth. Cultures were then shaken and incubated at $25^{\circ} \mathrm{C}$ for seven days in darkness. The mycelial growth were filtered from liquid culture under aseptic conditions and then frozen at ${ }^{-} 20^{\circ} \mathrm{C}$.

\section{DNA extraction and amplification}

The extraction was done according to commercial animal and fungi DNA preparation kit protocol. Genomic DNA was used as template for PCR amplification of ITS region using universal primers ITS5/ITS4 (White et al. 1990). The PCR reactions were performed in a final volume of $50 \mu \mathrm{l}$ containing $25 \mu \mathrm{l} 2 \mathrm{x}$ Taq PCR Master Mix, $2 \mu \mathrm{l}$ of each reverse and forward primer (20 pml), $2 \mu$ l of genomic DNA (30-100 ng/ $\mu \mathrm{l})$ and $19 \mu \mathrm{l}$ of RNase- Free water. Amplification was performed in a GeneAmp
PCR System 9700 thermocycler (Applied Biosystems) according to a program as follow: $95 \mathrm{C}$ for $3 \mathrm{~min}$, followed by 35 cycles of $95 \mathrm{C}$ for $30 \mathrm{~s}, 55 \mathrm{C}$ for $30 \mathrm{~s}, 72 \mathrm{C}$ for $45 \mathrm{~s}$ and final extension step of $72 \mathrm{C}$ for $10 \mathrm{~min}$.

Amplified PCR products were visualized by $1 \%$ agarose gel electrophoresis. The sequencing was performed at Macrogen Company, Korea. The sequences were checked and aligned using BioEdit sequence alignment editor 7.0.0 (Isis Pharmaceuticals, Inc., Carlsbad, CA, USA). The sequence was submitted to GenBank (Genbank accession MH374537). The similarity of the sequence with homologous sequences deposited in GenBank was calculated using the "BLAST" tool on the National Center for Biotechnology Information (NCBI) website. Alignment of selected sequences was done with clastalW. The phylogenetic tree was constructed using the Neighbor-Joining method by Jukes-Cantor model with MEGA7. Branch support was estimated by bootstrap analysis with 1000 replicates.

Mass production of an endophyticB. bassiana

Two grains,viz, wheat and rice used for estimating the biomass of the endophyticB.bassiana isolate at $25^{\circ} \mathrm{C}$ as liquid and solid medium.

\section{Liquid medium:}

For each wheat and rice, $20 \mathrm{~g}$ of grain washed well and boiled in distilled water for 1 hr. meshed properly and filtered. The size of filtration completed to one liter with distilled water. The grain mediums $(250 \mathrm{ml})$ packed separately in individual conical flask $(500 \mathrm{ml})$ with three replicates/ medium/ dry period. They plugged with cotton wool and autoclaved at $121^{\circ} \mathrm{C}$. After cooling, each flask inoculated with $1 \mathrm{ml}$ of the fungal suspension $\left(1 \times 10^{7}\right)$. For control treatment, the sterilized distilled water was inoculated with fungal suspension and then the flasks were incubated at $25^{\circ} \mathrm{C}$ for 21 days. All these procedures were done under laminar air flow chamber. After 21 days incubation, the flasks were agitated and filtered through filter paper. The fungal mat dried at laboratory temperature to determine the weight, spore concentration and spore germination in each grain medium after 1, 5 and 10 days of drying.

\section{Solid medium:}

Amount of rice and wheat grains was washed and socked with tap water for $2 \mathrm{hr}$ (rice grains) and $12 \mathrm{hr}$ (wheat grains), then the excess water 
drained completely. One hundred gram of each grain was put in $500 \mathrm{ml}$ flasks. To each of these flasks, $2 \mathrm{~g}$ of calcium carbonate and $2 \mathrm{~g}$ of calcium sulphate was added and mixed thoroughly to get uniform coating of salts over grains. This process will be help in preventing the grain particles sticking together and thereby providing more surface area for fungal growth. The flasks plugged with cotton wool and autoclaved at $121^{\circ} \mathrm{C}$ for sterilization. After cooling, each flask was inoculated with $1 \mathrm{ml}$ of the fungal suspension $\left(1 \times 10^{7}\right)$ under aseptic conditions and incubated for 21 days at $25^{\circ} \mathrm{C}$ for the production of aerial conidia. Three replications / medium/ dry period were used. After 21 days of incubation, grains with fungal growth were dried under aseptic conditions at lab temperature to record the mass of fungus, spore production and spore germination after 1, 5 and 10 days of drying date.

The data were statistically analyzed by SAS program using Complete Randomized Design (CRD) with three replicates and the means were compared using Duncan's multiple range tests at $\mathrm{P} \leq 0.05$.

\section{RESULTS}

\section{Identification}

The results of rDNA-ITS sequencing of the Beauveria isolate showed 609 bp of special DNA fragments sequenced. Using blast search, to compare the resulting sequence with sequences of rDNA accessed in Genbank, phylogentic analysis showed that the obtained sequences shares $99 \%$ homology to Beauveriabassianastrains: Chines isolates (KP994951, MG844431, MG844430); Spanish isolate (KC753391); South Africa isolates (MF802492,JX110376); Turkish isolate (FJ177439) and Mexico isolate (JN379811) (Fig.1). Together, morphological and molecular identification showed that ourBeauveriaisolateisB.bassiana(Genbank accession No. MH374537).

\section{Mass production \\ Liquid medium}

The results showed that the mycelia weight for B. bassiana was significantly affected by the type of media (Tab.2) and also the weight was decreased after each drying period. Between the two liquid media, rice medium produced maximum biomass; the highest weight of mycelia biomass reached to $0.72 \mathrm{~g} / 250 \mathrm{ml}$ of medium which recorded with rice after one day drying and significantly not differ with the weight 


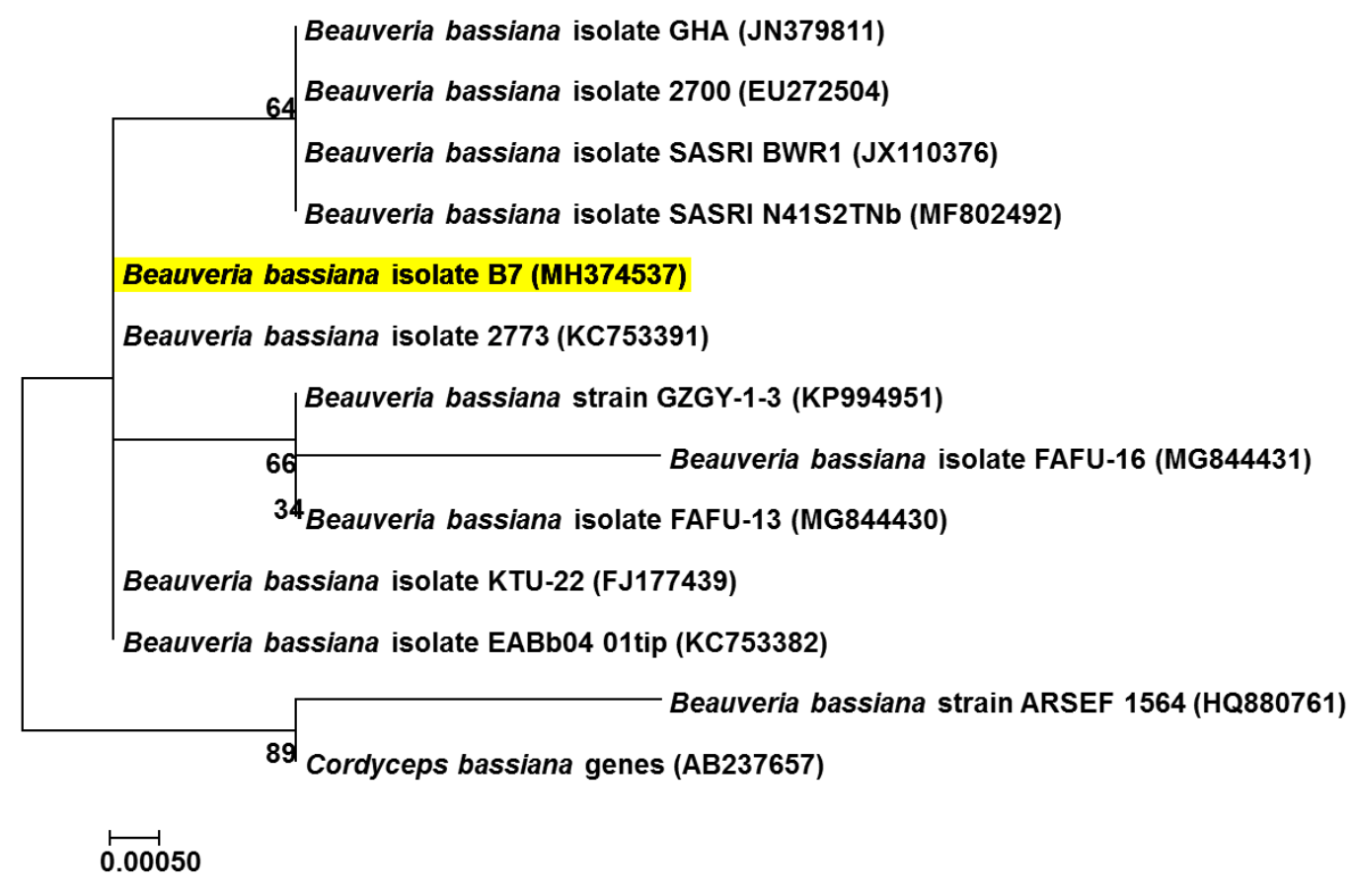

Fig. (1):Phylogenetic tree of Beauveriabassiana based on Neighbor-Joining analysis with 1000 bootstrap replicates of ITS-rDNA sequences of the new strain from Iraq (in yellow) and related Beauveria species from

GenBank. GenBank accession numbers provided behind the species names.

recorded after 5 and 10 days drying on the same medium as 0.68 and $0.67 \mathrm{~g} / 250 \mathrm{ml}$ medium. The lowest weight was $0.55 \mathrm{~g} / 250 \mathrm{ml}$ recorded on wheat liquid medium. The $B$. bassianawas also produced a significantly much higher amount of conidia when cultured with rice medium as $6.1 \times 10^{6}$ conidia/ $\mathrm{ml}$ suspension after ten day drying compared to $4.1 \times 10^{5}$ on wheat medium for the same drying period (Tab 2). The results also showed that the concentration of conidia/ $\mathrm{ml}$ was increased gradually after each drying period but significantly not differ.

Table (2): Biomass production of Beauveriabassiana on wheat and rice grains as liquid medium

\begin{tabular}{|c|c|c|c|c|}
\hline Medium & $\begin{array}{c}\text { Drying period } \\
\text { (Days) }\end{array}$ & $\begin{array}{c}\text { Weight gm./ } 250 \mathrm{ml} \\
\text { culture }\end{array}$ & $\begin{array}{c}\text { Concentration } \\
\text { Conidia/ml }\end{array}$ & Germination \% \\
\hline \multirow[t]{3}{*}{ Wheat } & 1 & $0.63 \pm 0.02 \quad b$ & $1.2 \times 10^{5} \mathrm{~b}$ & $99.67 \pm 4.84 \mathrm{a}$ \\
\hline & 5 & $0.61 \pm 0.02$ & $2.6 \times 10^{5} \mathrm{~b}$ & $97.33 \pm 2.60 \mathrm{a}$ \\
\hline & 10 & $0.55 \pm 0.01$ & $4.1 \times 10^{5} \mathrm{~b}$ & $91.33 \pm 0.58 \mathrm{ab}$ \\
\hline \multirow[t]{3}{*}{ Rice } & 1 & $0.72 \pm 0.02$ & $2.2 \times 10^{6} \mathrm{a}$ & $82.12 \pm 2.87 b$ \\
\hline & 5 & $0.68 \pm 0.05 \quad a b$ & $4.6 \times 10^{6} \mathrm{a}$ & $80.33 \pm 2.67 b$ \\
\hline & 10 & $0.67 \pm 0.02 \quad a b$ & $6.1 \times 10^{6} \mathrm{a}$ & $80.09 \pm 2.89 b$ \\
\hline \multicolumn{2}{|c|}{ Control } & $0.00 \mathrm{c}$ & $0.00 \mathrm{c}$ & $0.00 \mathrm{c}$ \\
\hline
\end{tabular}

Means followed by a common letters within the same column are not significantly differed at $5 \%$ level by DMRT.

Between the two liquid medium, conidia produced on wheat medium recorded the highest percentage of germination (Tab 2) which reached to $99.67 \%$. With liquid media based on wheat and rice, B. bassianaproduced conidia, blastospores (hyphal bodies) and hyphae (Fig. 2). Microsclerotia and newly reproduced conidia from hyphae were also observed within a short time. Among all the fungal cells, conidia with germ tubes treated as germination. 

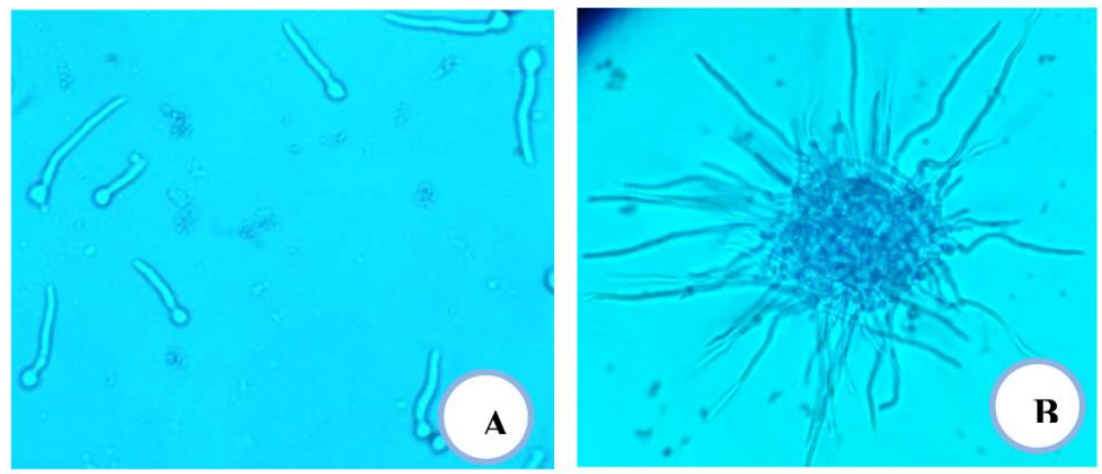

Fig. (2): Various morphologies as outcomes of germination of B. bassiana conidia (A: elongation of germ tube, B: Microsclerotia, scale bar A-B $=5 \mu \mathrm{m}$.

\section{Solid medium}

The largest weight of fungal dust was records on wheat grains after 10 days drying as $3.00 \mathrm{~g} /$ $100 \mathrm{~g}$ grains, and significantly differs with the weight recorded on rice grains as $2.38 \mathrm{~g} / 100 \mathrm{~g}$ grains.It's clear from data analysis, that the drying period had a significant effect on the weight of spore dust, the weight was increased by increasing the drying period, and the lowest weight was recorded after one day drying as 1.11 $\mathrm{g} / 100 \mathrm{~g}$ rice grains. This increasing of weight may due to that the drying help to separate the spores from the grains (Tab. 3).

Table (3): Biomass production of Beauveriabassiana isolates on wheat and rice grains as solid medium

\begin{tabular}{ccccc}
\hline Grains & $\begin{array}{c}\text { Drying period } \\
\text { (Days) }\end{array}$ & $\begin{array}{c}\text { Weight } \\
\text { gm./100gm. culture }\end{array}$ & $\begin{array}{c}\text { Concentration } \\
\text { Conidia/ml }\end{array}$ & $\begin{array}{c}\text { Germination } \\
\%\end{array}$ \\
\hline \multirow{2}{*}{ Wheat } & 1 & $1.11 \pm 0.13 \mathrm{c}$ & $2.7 \times 10^{6} \mathrm{~b}$ & $90.33 \pm 4.88 \mathrm{a}$ \\
\cline { 2 - 5 } & 5 & $2.60 \pm 0.21 \mathrm{a}$ & $3.0 \times 10^{6} \mathrm{~b}$ & $89.00 \pm 2.08 \mathrm{a}$ \\
\cline { 2 - 5 } & 10 & $3.00 \pm 0.21 \mathrm{a}$ & $5.0 \times 10^{6} \mathrm{a}$ & $88.33 \pm 3.03 \mathrm{a}$ \\
\hline \multirow{2}{*}{ Rice } & 1 & $1.13 \pm 0.11 \mathrm{c}$ & $1.4 \times 10^{5} \mathrm{~d}$ & $70.33 \pm 3.28 \mathrm{~b}$ \\
\cline { 2 - 5 } & 5 & $2.13 \pm 0.19 \mathrm{~b}$ & $3.5 \times 10^{5} \mathrm{~d}$ & $57.33 \pm 3.53 \mathrm{c}$ \\
\cline { 2 - 5 } & 10 & $2.38 \pm 0.19 \mathrm{ab}$ & $8.3 \times 10^{5} \mathrm{c}$ & $46.00 \pm 2.31 \mathrm{~d}$ \\
\hline
\end{tabular}

Means followed by a common letters within the same column are not significantly differed at $5 \%$ level by DMRT.

The concentration of conidia/ $\mathrm{ml}$ of fungal suspension were significantly affected by the type of media and not differ according to the drying periods. The highest spore production was recorded with $B$. bassiana cultured on wheat grains as $5.0 \times 10^{6}$ conidia/ $\mathrm{ml}$ after 10 days drying compared to $8.3 \times 10^{5}$ when cultured on rice grains. The lowest rate of germination was $46.00 \%$ after 10 days drying recorded with $B$. bassiana cultured on rice grains compared to $88.33 \%$ when cultured on wheat grains.

\section{DISCUSSION}

Beauveriabassiana along with other entomopathogenic fungi was previously isolated from the Iraqi soil (Assaf,2007; Assafet al. 2011;Abdullah and Mohamed Amin,2009; Abdullahet al. 2015) which depended on morphological characteristics for species identification. In this study $B$. bassiana as an endophytic isolated from cucumber leaves is newly reported in Iraq and identified by ITSrDNA based phylogentic analysis which is a sufficient marker for identifying $B$. bassiana 
from closely related species (Tuand Kirschner 2014).

Cultivation of endophytic B. bassiana isolate on rice and wheat grains as liquid and solid media have shown that the fungal weight, sporulation and germination differs significantly between two grains. B. bassiana achieved the maximum weight and sporulation when cultured on rice based medium as liquid (cooked rice) compared to wheat based medium. Inverse results recorded in case of solid media, that the maximum weight of $B$. bassiana achieved on wheat compared to rice medium. The two different substrates (wheat and rice) supported growth of the of $B$. bassiana, confirming the earlier work (Ibrahimand Low 1993; Sergioet al. 2003; Fenget al. 2004) that fungi can be costeffectively mass- produced on different solid substrates.Bhadauriaet al. (2012) who used 15 various grains as solid media for $B$. bassiana mass production recorded a dry weight of fungus as 0.378 and $0.555 \mathrm{~g} / 100 \mathrm{~g}$ of wheat and rice grains, respectively. Ibrahimet al. (2015) stated that the $B$. bassiana dry weight per 100 gram of substrate was highly variable and recorded a weight as 20.7, 5.0 and $1.3 \mathrm{~g} / 100 \mathrm{~g}$ for burgul, rice, and wheat, respectively. Latifian et al. (2013) reported that $B$. bassiana cultured on liquid medium of rice produced significantly higher spore production $\left(3.3 \times 10^{7}\right.$ conidia/ $\left.\mathrm{ml}\right)$ compared to conidia produced on liquid wheat medium (5.1 x 10). Gouliet al. (2014) reported that an increase in the depth of the liquid biomass in the cultivation container led to decrease in the yield of aerial conidia/ $\mathrm{ml}$ of initial fungal biomass.

Conidia produced on wheat medium recorded the highest percentage of germination which reached to $99.67 \%$ after one day of drying. The rate of germination is an important factor in the infection process, with faster germinating conidia generally considered to have a greater chance of causing infection. However, germination rates on the cuticle may not reflect those seen on artificial media because of the presence of anti- fungal compounds associated with the cuticle (Charnley 1989).BinandMitsuaki(2006) revealed that $B$. bassianacould germinate and extend hypha in sterilized distilled water. They recorded, just one-week after inoculation, visible long mycelia but the new mycelia showed degradation after 4 weeks survival; perhaps because of exhaustion of nutrients stored in the conidia. They also mentioned that the nutritional conditions in water are thought to be poorer compared with soil, that may limit the germination of $B$. bassianain sterilized water, and keep it at a low level. The conidia may quickly lose their viability when they exhausted their own stored nutrients.

With liquid media based on rice and wheat, $B$. bassiana conidia produced germ tubes, blastospores (hyphal bodies) and hyphae. Fargues et al. (1979) reported that both B.bassiana and B. brongniartii had the ability to produce blastospores in liquid media, but it is difficult to storage and kept their viability for long time (Ferron 1981). Brownet al. (1988) reported that the fungal biomass is increased via vegetative growth forming either hyphal filaments, often with copious branching, or various forms of pellets of mycelia depending on the strain, medium, and culture parameters. The majorities of fungal isolates are also capable of forming single cells via schizolytic separation at the septa or mechanical fragmentation of the hyphae, and can also be generated from the hyphae by yeast-like budding (Jacksonet al. 1997). In general, nutrient-rich media containing high concentrations of carbon and nitrogen sources are more likely to produce larger quantities of these vegetative propagules (blastospores, hyphal bodies, mycelium, and microsclerotia). Blastospores of B. bassiana and I. fumosorosea have been obtained in liquid cultures amended with high concentrations of glucose, under high aeration rates, and an appropriate source of nitrogen to yield high concentrations of blastospores(Jaronski and Mascarin 2013; Mascarinet al. 2015).

\section{REFERENCES}

Abdullah S.K and
AminM.K.(2009).Occurrence of $\begin{array}{r}\text { Mohamed } \\ \text { insect }\end{array}$
Basrah,Iraq.Proceeding of the $1^{\text {st }}$ Scientific
Conference for Biological Sciences.22-23
April.2009. University of Mosul,Iraq.P.222-
227.
Abdullah $\quad$ S.K, Mustafa
AssafL.H.(2015).Isolation
entomopathogenic and opportunistic fungi
from soil in Duhokprovince,Kurdistan Region


of Iraq by different selective media. Journal of Biology,Agriculture and Healthcare 5(4):7379.

Akello J., Dubois T., Gold C., Coyne D., Nakavuma J., Paparu P. (2007): Beauveriabassiana (Balsamo) Vuillemin as an endophyte in tissue culture banana (Musa spp.). J. Invertebr. Pathol. 96: 34-42.

Arnold A. E. (2007).Understanding the diversity of foliar endophytic fungi: progress, challenges, and frontiers. Fungal Biology Reviews 21: 5166.

Arnold A.E. and Lewis L.C. (2005).Ecology and evolution of fungal endophytes, and their roles against insects. In: Vega, F.E., Blackwell, M. (Eds.), Insect-Fungal Associations: Ecology and Evolution. Oxford University Press, NewYork, pp. 74-96.

AssafL.H. (2007).Ecological study and evaluation of activity of Beauvariabassiana (Bals.)Vuill.andPaecilomycesfarinosus (Dicks ex Fr.) on some biological aspects of sun pest on wheat (Ph.D thesis).University of Mosul, College of Agriculture and Forestry, Iraq, 231pp. (In Arabic).

AssafL.H.,HaleemR.Aand Abdullah S.K. (2011).Association of entomopathogenic and other opportunistic fungi with insects in dormant locations. Jordan Journal of Biological Sciences 4:87-92.

Bhadauria B.P., Puri S., Singh P.K. (2012).Mass production of entomopathogenic fungi using Agricultural products. The bioscan, 7: 229-232.

Bills G.F. and Polishook J.D. (1991).Microfungi from Carpinuscaroliniana. Canadian Journal of Botany 69: 1477-1482.

Bin W. andMitsuaki S. (2006): Density dynamics of an entomopathogenic fungus, Beauveriabassiana introduced into fresh water. (Bulletin of FFPRI) 5: 227-233.

Brown D.E. (1988). The submerged culture of flamentous fungi. In: Berry DR, editor. Physiology of Industrial Fungi. Blackwell Scientific Publications; pp. 219-248.

Brownbridge M., Reay S.D., Nelson T.L. and Glare T.R.(2012). Persistence of Beauveriabassiana (Ascomycota: Hypocreales) as an endophyte following inoculation ofradiata pine seed and seedlings. Biol. Control 61: 194-200.

Charnley A.K. (1989). Mycoinsecticides: present use and future prospects. Progress and prospects in insect control. Br. Crop prot. Council Monogr: 43: $165-181$.

DoberskiJ.W. and Tribe H.T. (1980).Isolation of entomogenous fungi from elm bark and soil with reference to ecology of Beauveriabassiana and Metarhiziumanisopli ae.Transactions of the British Mycological Society74: 95-100.

DongaT.K., Vega F.E and Klingen I.(2018).Establishment of the fungal entomopathogenBeauveriabassiana as an endophyte in sugarcane Saccharumofficinarum.Fungal Ecology 35:7077

Evans H.C., Holmes K.A. and Thomas S.E. (2003).Endophytes and mycoparasites associated with an indigenous forest tree, Theobromagileri, in Ecuador and a preliminary assessment of their potential as biocontrol agents of cocoa diseases. Mycological Progress 2: 149-160.

Fargues J., Robert P.H. and Reisinger O. (1979).Formulation des productions de masse de

phypomyceteentomopathogeneBeauveriabassi ana en vue des applications phytosanitaires.Annales de zoologie- Ecologic Animale 11: 247- 257.

Feng M.G., Pu X.Y., Ying S.H. and Wang Y.G. (2004). Field trials of an oil based emulsifiable formulation of Beauveriabassiana conidia and low application rates of imidacloprid for control of false-eyed leafhopper Empoascavitis in Southern china. Journal of Crop Protection 23: 489-496.

Ferron P. (1981). Pest control by the fungi Beauveria and Metarhizium. (In:) H.D. Burges (ed.). Microbial control of pest and plant diseases, 1970-1980., Academic Press, London: 465482.

Ganley R.J. and Newcombe G.(2005).Fungal endophytes in seeds and needles of 
Pinusmonticola. Mycological Research 110: 318-327.

Gouli V, Gouli S. and Kim J. S. (2014). Production of BeauveriabassianaAir Conidia by Means of Optimization of Biphasic System Technology. Braz. Arch. Biol. Technol. 57: 571-577.

Gurulingappa P., Sword G.A., Murdoch G. and McGee P.A. (2010). Colonization of crop plants by fungal entomopathogens and their effects on two insect pests when in planta. Biol. Control 55: 34-41.

Huang W.Y., Cai Y. Z., Xing J., Corke H. and Sun M. (2007). Potential antioxidant resource: endophytic fungi isolated from traditional Chinese medicinal plants. Economic Botany 61: $14-30$.

Hyde K.D. andSoytongk. (2008).The fungal endophyte dilemma. Fungal Diversity 33:163173.

Ibrahim L., Laham L., Touma A. and Ibrahim S. (2015).Mass Production, Yield, Quality, Formulation and Efficacy of EntomopathogenicMetarhiziumanisopliae conidia. British Journal of Applied Science and Technology 9: 427-440.

Ibrahim Y.B. and Low W. (1993). Potential of Mass Production and Field Efficacy of Isolates of the EntomopathoghenicFungi Beauveriabassiana and Paecilomycesfumosoroseus on Plutellaxylostella. J.Invertebr. Pathol. 39: 222232.

Jackson M., McGuire M., Lacey L. andWraight S. (1997).Liquid culture production of desiccation tolerant blastospores of the bioinsecticidal fungus Paecilomycesfumosoroseus. Mycol. Res. 101: 35-41.

Jaronski1S.T. and Mascarin G.M. (2013). Mass Production of Fungal Entomopathogens: State of the Art chapter 9, pp 141-155.

Jenkins N.A. and Prior C. (1993).Growth and formation of try conidia by Metarhiziumflavoviridae in a simple liquid medium. Mycol. Res. 97: 1489-1494.

Jones K.D. (1994). Aspects of the biology and biological control of the European corn borer in North Carolina.Ph.D Thesis, Department of Entomology, North Carolina State University.
Kassa A.,Brownbridge M., Parker B.L., Skinner M., Gouli V., Gouli S., Guo M., Lee F. and Hata T. (2008).Whey for mass production of Beauveriabassiana and Metarhiziumanisopliae.Mycol Res.112: 583591.

Latifian M., Rad B., Amani M. and Rahkhodaei E. (2013).Mass production of entomopathogenic fungi Beauveriabassiana (Balsamo) by using agricultural products based on liquid- solid diphasic method for date palm pest control. Intl J Agri Crop Sci. 5: 2337-2341,

Leckie B.M. (2002). Effects of Beauveriabassiana mycelia and metabolites incorporated into synthetic diet and fed to larval Helicoverpazea, and detection of endophyticBeauveriabassiana in tomato plants using PCR and ITS. M.Sc. Thesis, Department of Entomology, the University of Tennessee.

Leite L.G., Batista-Filho A., Almeida J.E.M. and Alves S.B. (2002). Technical aspects of the industrial production of entomopathogenic fungi in Brazil. In: 35th Annual Meeting of the Society of Invertebrate Pathology: Proceedings: Contributed abstracts; Foz do Iguaçu, Brazil: Embrapa. pp193.

Machado A. C. R., Monteiro A. C., de Almeida A. M. B. and Martins M. I. E. G. (2010): Production technology for entomopathogenic fungus using a biphasic culture system. Pesqagropec bras Brasilia 45: 1157-63.

Mascarin G.M., Jackson M.A., Kobori N.N., Behle R.W. andDelaliberaJr. I.(2015). Liquid culture fermentation for rapid production of desiccation tolerant blastospores of Beauveriabassianaand

Isariafumosoroseastrains. J. Invertebr. Pathol. 127: 11-20.

NorilerS.A.,SaviD.C.,AlaizioR.,Palecro-

CortesA.M.,Possiede Y.M

andglienkeC.(2018).Bioprospecting and structure of fungal endophyte communities found in the Brazilian

Biomass,Pantanalandceerrado. Front.Microbiol.9:1526.

Posada F., Aime M.C., Peterson S.W., Rehner S.A. and Vega F.E. (2007). Inoculation of coffee 
plants with the fungal entomopathogen Beauveriabassiana (Ascomyc ota: Hypocreales). Mycol Res 111:748-757

Quesada-Moraga E., Landa B.B., Muñz-Ledesma J., Jime'nez-D1'az R.M. and Santiago-A' lvarez, C. (2006).Endophytic colonization of Opium poppy, Papaversomniferum, by an entomopathogenicBeauveriabassianastrain.My copathologia 161: 323-329.

RamosY., Portal O.,LysoeE.,Meyling N.V andklingenI. (2017): Diversity and abundance of Beauveriabassiana in soils, stink bugs and plant tissues of common bean from organic and conventional fields. Journal of Invertebrate Pathology 150:114-120

Sergio O., Pablo S. and Martin A. (2003). Native and Introduced Host Plants of Anastrephafraterculus and Ceratitiscapitata (Diptera: Tephritidae) in Northwestern Argentina. Journal of Economic Entomology 96: $1108-1118$.

Sikura A.I. andPrimak T.A. (1970).Native formulation of Boverin.Microbiological Industry of Soviet Union, Department of Information, Moscow; 1970. P. 1-44.

Strobel G.A. (2003). Endophytes as sources of bioactive products. Microbes and Infection, 5:535-544.

Tefera T. and Vidal S. (2009).Effect of inoculation method and plant growth medium onendophytic colonization of sorghum by the entomopathogenic fungus

Beauveriabassiana.BioControl 54: 663-669.

Tu C.Cand KrischnerR. (2014). ITS barcodes for Beauveriabassiana in Taiwan.Fung.Sci.29:3341.

Vakili N.G. (1990). Biocontrol of stalk rot in corn, pp. 87-105. In: Proceedings of the Forty-fourth Annual Corn and Sorghum Industry Research Conference, December 6-7, 1989, Chicago, IL. AmericanSeed Trade Association, Washington, DC.

Vega F.E. (2018). The use of fungal entomopathogens as endophytes in biological control: a review. Mycologia 110:4-30

White T.1., Bmns T., Lee S. and Taylor, 1. (1990). Amplification and Direct Sequencing of Fungal Ribosomal RNA Genes for PhylogeneticsIn: PCR Protocols: AGuide to Methods and Applications (eds. M. AInnis, D.H.Gelfand, II Sninsky and TJ.White). Academic Press, SanDiego, California: 315-322.

Wilson D. (1995). Endophyte: the evolution of a term, and clarification of its use and definition. Oikos 73: 274-276.

Zheng R.Y and Jiang H.(1995). Rhizomucorendophyticus sp.nov.,anendophyticzygomycetes from higher plants. Mycotaxon 56:455-466. 
يشكنينا كه رديلهيى و و زيّدهكرنا كه روويى نخافتى Beauveria bassiana(Bals.) Vuill.

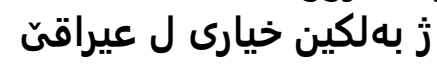

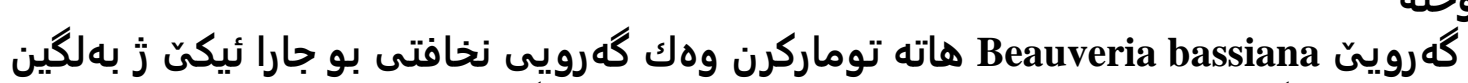

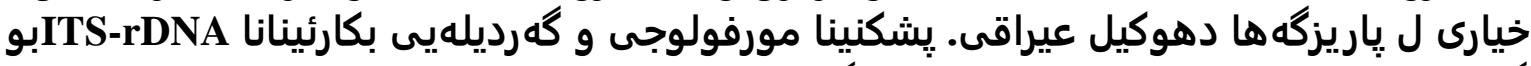

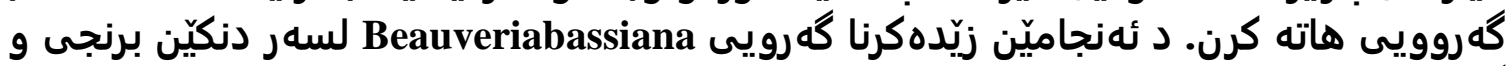

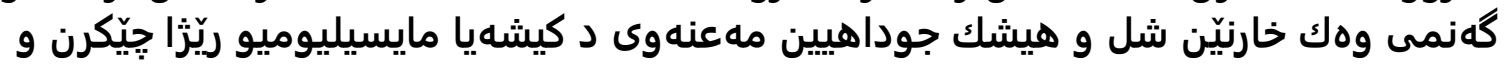

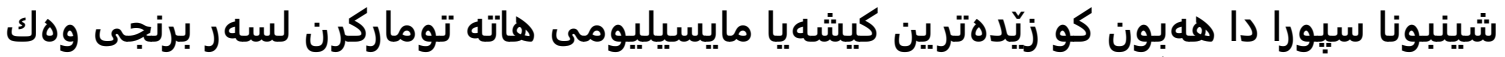

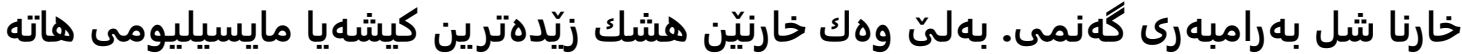

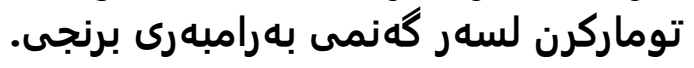

$$
\begin{gathered}
\text { Beauveria bassiana(Bals.) Vuill. التصنيف الجزيئي و اكثار الفطر الكامن اوراق نبات الخيار في العراق اق من }
\end{gathered}
$$

تم تسجيل الفطر .Beauveria bassiana(Bals.) Vuill كفطر كامن لاول مرة من اوراق نبات

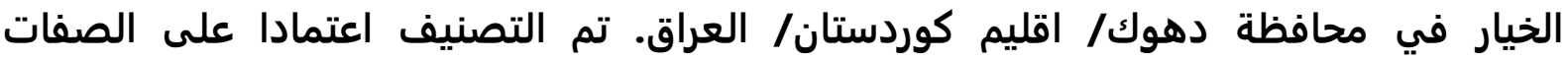

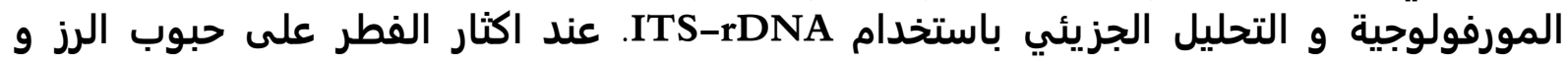

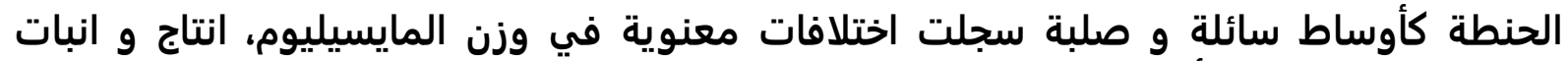

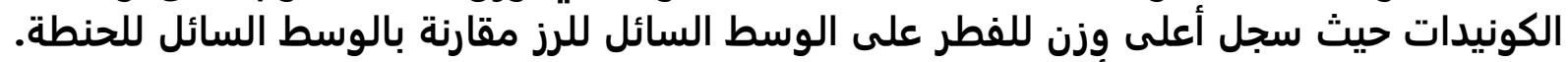
في حالة الاوساط الصلبة فأن النتائج كانت عكسية حيث سجل الفيثلى اعلى وزن على الحنطة مقارنة بالرز. 